\title{
KNOWLEDGE SHARING IS THE KEY FOR THE PROGRESS OF SCIENCE
}

\author{
SANDOR G. VARI \\ International Research and Innovation in Medicine Program, Cedars-Sinai Medical \\ Center, Los Angeles, CA, USA \& RECOOP HST Association; \\ e-mail: vari@cshs.org
}

K nowledge transfer began with the Sumerians, the earliest known civilization in the Bronze Age. Sumerians developed the initial documentation of their life in writing around 3,500-3,200 BC. In China, the educated people knew Chinese characters at about 4,000 BC. The Mycenaeans, an early tribe of Greeks between 1500 and $1200 \mathrm{BC}$, adapted the Minoan syllabary to write an early form of Greek. Greek became the language of medicine in the Roman Empire, however in the $4^{\text {th }}$ Century AD, Latin gradually began to be used as the common medical language. The written and spoken Latin language was used for hundreds of years after the fall of the Roman Empire and many European languages still use the Roman alphabet today.

Just 600 years ago during the Renaissance, the scientific revolution took place in Europe. In modern-day societies, science has become professionalized. The Latin language became the common language of medicine and from the late medieval period to the mid-17th Century, Latin was also the dominant language in science. In the $18^{\text {th }}$ Century this situation changed rapidly and besides Latin, science was also published in German, French and English. World War I changed the landscape of scientific communication, due to the boycott of the German language published by French and Englishspeaking scientists. In parallel from the early 1900s, many international organizations formed to govern science and they adopted English as their communication and publishing language. As transport and commerce became regional and later global, English became the communication language of business and diplomacy. In the last three decades of the $20^{\text {th }}$ Century, the fast-growing field of Information Technology and the World Wide Web made English the most popular language in the world.
Having a common language in science is not the only factor that has helped to foster knowledge sharing. In the second half of the $20^{\text {th }}$ Century, the integration and synthesis of knowledge across disciplines was necessary to implement the multidisciplinary sciences that accelerated research and development in agriculture to the space industry [1].

Knowledge sharing is the most important element of collaborative research [2]. In cross-disciplinary collaborations, individual research work must be adapted to coordinate with other individual research works and researchers must discuss their results extensively in workshops and at conferences [3]. These are the reasons why in 2006, Cedars-Sinai Medical Center (CSMC) with eleven Central and Eastern European (CEE) universities and academic organizations from six countries (Croatia, Czech Republic, Hungary, Romania, Slovakia, and Ukraine) formed the Regional Cooperation for Health, Science and Technology (RECOOP HST) Consortium [4].

In 2012, CSMC and the CEE partner organizations agreed to form the Association for Regional Cooperation in the Fields of Health, Science and Technology (RECOOP HST Association https:// www.cedars-sinai.edu/Research/Research-Administration/Recoop/). RECOOP is a strategic partnership provides added value to both CSMC and the CEE organizations. RECOOP organizes meetings and conferences that help the participating scientists to understand the most important element of knowledge sharing: within collaborative research work each member depends on the group and building of trust within the group is the key to success. At the same time however, it is necessary to empower the participating scientist to be creative and autonomous [5].

In RECOOP science enables researchers to be creative and motivate researchers to acquire

(C) 2018 Vari S. G. This is an open-access article distributed under the terms of the Creative Commons Attribution License, which permits unrestricted use, distribution, and reproduction in any medium, provided the original author and source are credited. 
knowledge needed by every university graduate, $\mathrm{PhD}$ student and postdoc. It is also useful in the selection of future researchers and teachers. Science is not perfect and sometimes produces controversial results, but at the same time it teaches analytical thinking skills that are very valuable in modern societies.

Scientists should share their raw data in ways that are easily accessible and digestible, and it is necessary that the published findings can be reanalyzed or replicated by others. Scientists need to publish the methods and findings more completely and science should be more transparent. Production of new knowledge in medicine is immeasurably facilitated by the enrichment of opportunities provided by efficient trans-national multidisciplinary scientific partnerships and collaborations like the RECOOP HST Association [6]. The RECOOP HST Association enables the opportunity for development of diverse talents in different specialties, all geared towards sharing and integrating knowledge.

\section{References}

1. Melmed S, Vari SG. Challenges in life sciences and health systems in the 21st century. Croat Med J. 2014; 55(3): 184-185.

2. Park J, Gabbard JL. Factors that affect scientists' knowledge sharing behavior in health and life sciences research communities: Differences between explicit and implicit knowledge. Comput Human Behav. 2018; 78: 326-335.

3. Puljak L, Vari SG. Significance of research networking for enhancing collaboration and research productivity. Croat Med J. 2014; 55(3): 181-183.

4. Vari SG. Review Research Activities in RECOOP HST Consortium. Biopolym Cell. 2011; 27: 84.

5. Vari SG. Key elements of networking in life sciences: collective creative thinking and team work. Croat Med J. 2015; 56(2): 75-77.

6. Vari SG. Creative mind links art and science. Croat Med J. 2016; 57(2): 87-88. 